\title{
Synthesis and Characterization of 5-Substituted- (2-methylbenzimidazol-1-yl)-1,3,4-oxadiazole-2-thione and Its Metal Complexes of Fe(III), Hg(II), Zn(II) and Sn(II)
}

\author{
SHABBIR A KAZI \\ Department of Chemistry, Mangalore University, Mangalore-574 199, India \\ Department of Chemistry Anjuman Engineering College, Bhatkal-581 320, Karnataka, India \\ sakazi99@yahoo.com
}

Received 19 November 2013 / Accepted 29 December 2013

\begin{abstract}
A ligand 5-Substituted-(2-methylbenzimidazol-1-yl)-1,3,4-oxadiazole-2-thione (L) and its $\mathrm{Fe}(\mathrm{III}), \mathrm{Hg}(\mathrm{II}), \mathrm{Sn}(\mathrm{II})$ and $\mathrm{Zn}(\mathrm{II})$ complexes were synthesized. The authenticity of the ligand and its transition metal complexes were established by elemental analyses, conductance and magnetic susceptibility measurements, as well as spectroscopic (IR, ${ }^{1} \mathrm{H}$ NMR, UV-Vis and Mass) and thermal studies. All complexes exhibit the composition $\mathrm{ML}_{2} \mathrm{X}_{2}$ where $\mathrm{M}=\mathrm{Fe}$ (III), $\mathrm{Hg}(\mathrm{II}), \mathrm{Zn}$ (II) and $\mathrm{Sn}(\mathrm{II}), \mathrm{L}=$ Ligand, $\mathrm{X}=\mathrm{OAc}$ and chloride ions. The IR spectral studies revealed the existence thiol-thione tautamerism in the ligand molecule. The ligand acts as a bidentate coordinating through the N-3 nitrogen and the exocyclic sulfur atoms of ox diazole rings. Antimicrobial screening of the ligand and its metal complexes were determined against the bacteria Escherichia coli and Salmonella paratyphi A.
\end{abstract}

Keywords: Oxadiazoles, Benzimidazoles, Transition metal complexes, Electronic spectra, IR spectra, Biological activity

\section{Introduction}

Benzimidazole derivatives play vital role in biological field such as antimicrobial, antiviral, anti-diabetic and anticancer activity ${ }^{1}$. Therapeutic significance of these clinically useful drugs in treatment of microbial infections encouraged the development of some more potent and significant compounds. Benzimidazoles are remarkably effective compounds both with respect to their bacteria inhibitory activity and their favorable selectivity ratio $^{2}$. Benzimidazoles are regarded as a promising class of bioactive heterocyclic compounds that exhibit a range of biological activities ${ }^{2}$. Specifically, this nucleus is a constituent ${ }^{2}$ of vitamin- $\mathrm{B}_{12}$.

On the other hand 1,3,4-Oxadiazoles are of considerable pharmaceutical and material interest ${ }^{3-5}$. They have been shown to possess muscle relaxant, anti mitotic, analgesic, anti- 
inflammatory, anticonvulsive, diuretic and anti-emetic properties ${ }^{3-5}$. They also possess tranquilizing, anti-tubercular, hypoglycemic, herbicidal, antiviral, amoebicidal, insecticidal, hypnotic and sedative activities. Some material applications of 1,3,4-oxadiazole derivatives lie in the field of liquid crystals ${ }^{5}$. Oxadiazole derivatives, which belong to an important group of heterocyclic compounds, have been the subject of extensive study in the recent past. Numerous reports have highlighted their chemistry and use ${ }^{3-5}$. Diverse biological activities, such as antituberculostatic, anti inflammatory, analgesic, antipyretic and anticonvulsant ${ }^{4}$, have been found to be associated with oxadiazole derivatives ${ }^{5}$. For this reason our aim was to synthesize various 1,3,4-oxadiazole-2-thione derivatives to make notable contributions to this class of heterocyclic compounds. We report the synthesis and characterization of some 5- substituted1,3,4-oxadiazole-2-thiones using the synthetic procedure based on the ring closure reactions of appropriate acid hydrazides with carbon disulphide. The heterocyclic thiones represent an important type of compound in the field of coordination chemistry because of their potential multifunctional donor sites, viz either exocyclic sulfur or endocyclic nitrogen ${ }^{6-7}$. There are a few reports on the metal complexes of 5-substituted-1,3,4-oxadiazole-2-thione ${ }^{4}$.To the best of our knowledge we are reporting for the first time metal complexes based on 1,3,4-oxadiazole2-thione containing 2-methyl-benzimidazole moiety (Figure 1).<smiles>Cc1nc2ccccc2n1Cc1nnc(S)o1</smiles>

T H IO L

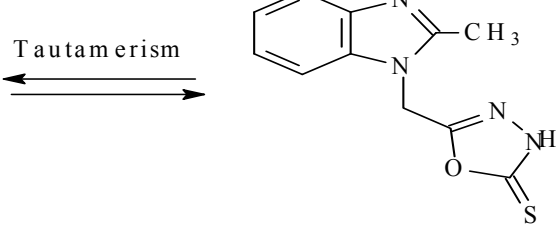

THIONE

Figure 1. Proposed structure of the title ligand

\section{Experimental}

Commercial reagents were used without further purification and all experiments were carried out in open atmosphere. All the solvents were purchased from Merck Chemicals, India, and used after purification.

Carbon, hydrogen and nitrogen contents were estimated on a Truspec model micro-analyser. By following standard procedures ${ }^{8}$, the complexes were analyzed for their metal content. For metal ion determination, a solution of the complex was first prepared by decomposing a known amount of complex with a mixture of conc. nitric acid and conc. sulfuric acid ${ }^{8-9}$. The digestion was continued with repeated addition of acid mixture to ensure complete decomposition of organic matter in the complex. The residue was extracted with distilled water and the metal contents were determined by standard methods. The sulfur was estimated as $\mathrm{BaSO}_{4}$ by gravimetric method ${ }^{8}$ and chloride was estimated by volumetric method ${ }^{8}$ using standard $\mathrm{AgNO}_{3}$ solution. The molar conductance measurements were made in DMSO with $10^{-3} \mathrm{M}$ solutions ${ }^{9}$ using an EI Conductivity meter, Type CC-01 with a cell constant of 1.02.

Magnetic susceptibility measurements were performed at room temperature on a Gouy balance using $\mathrm{Hg}[\mathrm{Co}(\mathrm{NCS}) 4]$ as the calibrant ${ }^{9}$.IR spectra were recorded in the $4,000-400 \mathrm{~cm}^{-1}$ region (for the lagans) IR Spectrophotometer PE FTIR and in $4000-200 \mathrm{~cm}^{-1}$ region (for metal complexes) on Nicolet instrument model MAGNA 550 spectrophotometer as $\mathrm{KBr}$ pellets ${ }^{11} .{ }^{1} \mathrm{H}$ NMR spectra were recorded in DMSO- $\mathrm{d}_{6}$ on Bruker AV III NMR spectrometer using TMS as internal reference. The EI- Mass spectrum was recorded on JEOL GC -MATE GC--MS Spectrometer using $70 \mathrm{eV}$ with a source temperature of $150{ }^{\circ} \mathrm{C}$. The thermal studies of the 
complexes were performed on a NETZSCH TGA/DTA/DSC Thermal analyzer under a nitrogen atmosphere at a heating rate of $10^{\circ} \mathrm{K} / \mathrm{min}$ in the temperature range of 50 to $1400{ }^{\circ} \mathrm{C}$.

\section{Synthesis of ligand}

Following steps are involved in the synthesis of ligand. The reactions involved in the synthesis of the ligand are shown in Scheme 1.

\section{Preparation of 2-methylbenzimidazole}

A mixture of $o$-phenylenediamine $(10 \mathrm{~g}, 0.1$ mole $) \&$ acetic acid $(8.4 \mathrm{~mL}, 0.14$ mole $)$ was heated under reflux for $2 \mathrm{~h}$. Then the reaction mixture was cooled $\&$ it was made alkaline by addition of sodium bicarbonate. The solid thus separated was collected by filtration and dried at $100{ }^{\circ} \mathrm{C}$. Yield, $6.5 \mathrm{~g}(60 \%) \mathrm{mp}, 172-174{ }^{\circ} \mathrm{C}$.

Synthesis of (2-Methylbenzimidazol-1-yl)-acetic acid ester ${ }^{2}$

A mixture of 2-methylbenzimidazole(1) (6.5 g, 0.05 mole), Ethyl chloroacetate $(10.0 \mathrm{~mL}$, $0.075 \mathrm{~mole})$ and potassium carbonate $(15 \mathrm{~g})$ in acetone $(100 \mathrm{~mL})$ as a solvent was refluxed for $6 \mathrm{~h}$. The reaction mixture was cooled to room temp and acetone was removed by distillation. Then the reaction mixture was transferred to ice cold water and it was stirred to dissolve the potassium carbonate. The solid ester thus separated was filtered, washed with water, dried and recrystalized with ethanol. Yield, $6.0 \mathrm{~g}(60 \%) \mathrm{mp}, 82-84{ }^{\circ} \mathrm{C}$.

\section{Synthesis of (2-Methylbenzimidazol-1-yl)-acetic acid hydazide ${ }^{2}$}

A mixture of (2-Methylbenzimidazol-1-yl) acetic acid ester(2) (5 g, 0.023 mole) and hydrazine hydrate $(3.0 \mathrm{~mL}, 0.058$ mole, $2.5 \mathrm{eqv})$ in ethanol $(25 \mathrm{~mL})$ as a solvent was refluxed for $4 \mathrm{~h}$. The solution on cooling gave solid mass of hydrazide. The solid was recrystalized with ethyl alcohol. Yield, $4.5 \mathrm{~g}(90 \%) \mathrm{mp}, 210-212{ }^{\circ} \mathrm{C}$.

Synthesis of 5-Substituted-(2-Methylbenzimidazol-1-yl)-1,3,4-oxadiazole-2-thione ${ }^{2}$ (MBIMOT)

To a solution of potassium hydroxide $(1.7 \mathrm{~g})$ in ethanol $(25 \mathrm{~mL})$ (2-methyl benzimidazol-1-yl)actic acid hydrazide (3) (4.0 g, 0.02 mole), was added followed by carbon disulfide ( $3.0 \mathrm{~mL}$, 0.04 mole). The reaction mixture was heated under reflux for $6 \mathrm{~h}$. Then the reaction mixture was allowed to cooled to room temp. Then it was concentrated, diluted with minimum amount of distilled water and acidified with $1 \mathrm{~N} \mathrm{HCl}$. The solid thus separated was collected by filtration. It was then washed with water dried and recrystalized with a mixture of methanol and DMF. The Scheme 1 shows the steps involved in the preparation of legand(4) MBIMOT.

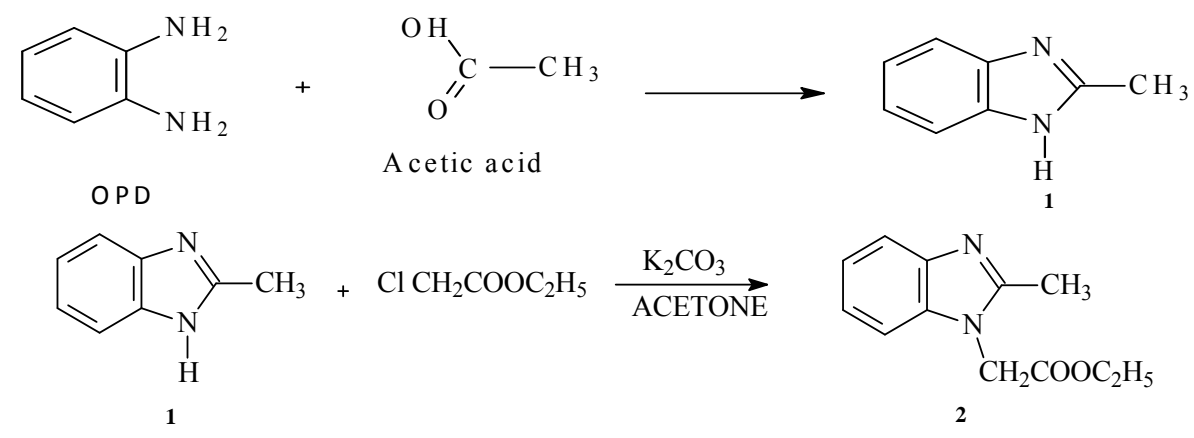




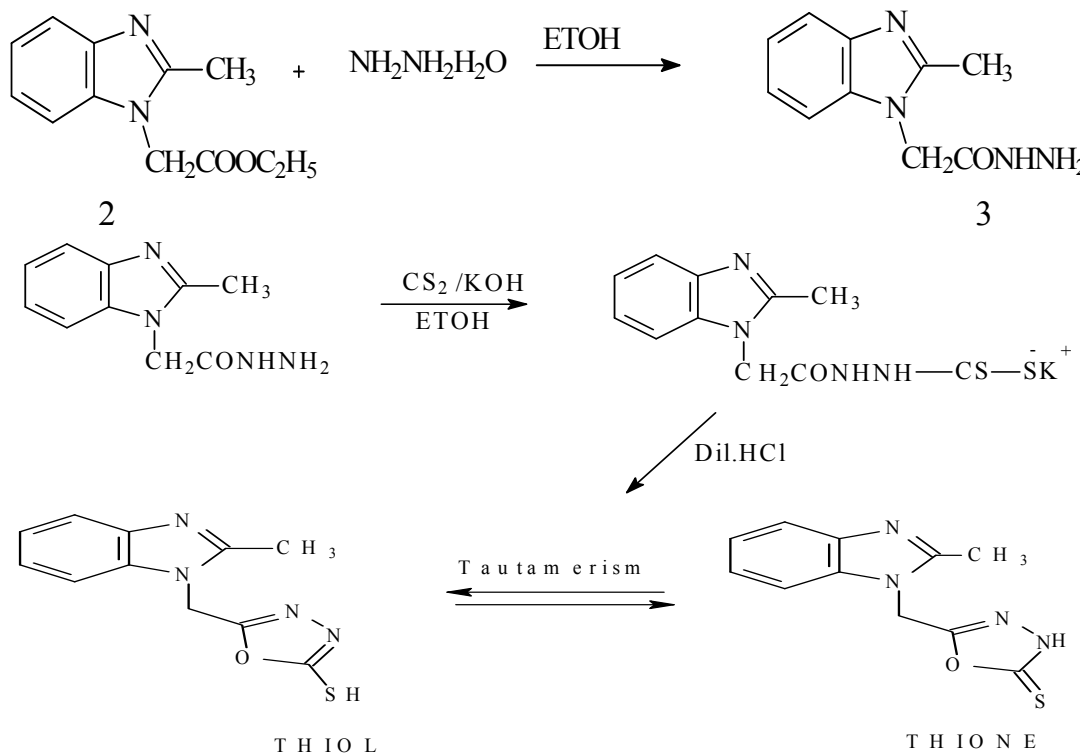

Scheme 1. Reactions involved in the synthesis of ligand

General procedure for preparation of metal complexes using MBIMOT as a ligand ${ }^{10-11}$ In the preparation of metal complexes of various transition metal ions using MBIMOT as a ligand a general procedure was followed ${ }^{10-11}$. The ligand and metal salts were taken in 2:1 ratio $^{10}$. The ligand was dissolved in DMF and the hot solution of ligand was mixed with a hot aqueous solution of various metal salts. The complexes were precipitated immediately. In some cases the precipitation occurred when $\mathrm{pH}$ of the solution was raised by the addition of sodium acetate. The precipitated complexes were allowed to stand for $1 \mathrm{~h}$ then filtered, washed with water and ether. Then dried and cooled in a desiccators. The analytical data of ligand and metal complexes is included in Table 1.

Table 1. Analytical data of MBIMOT(L) and its metal complexes

\begin{tabular}{|c|c|c|c|c|c|c|c|}
\hline \multirow{2}{*}{ Compounds (color) } & \multirow{2}{*}{$\begin{array}{l}\text { Mol } \\
\text {.wt. }\end{array}$} & \multicolumn{5}{|c|}{ Found (Calculated)\% } & \multirow[b]{2}{*}{$\mathrm{Cl}$} \\
\hline & & M & $\mathrm{C}$ & $\mathrm{H}$ & $\mathrm{N}$ & $\mathrm{S}$ & \\
\hline $\begin{array}{l}\mathrm{C}_{11} \mathrm{H}_{10} \mathrm{~N}_{4} \mathrm{OS} \text { Ligand } \\
\text { (Light Yellow) }\end{array}$ & 246 & - & $\begin{array}{c}53.60 \\
(53.65)\end{array}$ & $\begin{array}{c}4.00 \\
(4.09)\end{array}$ & $\begin{array}{l}22.65 \\
(22.75)\end{array}$ & $\begin{array}{l}12.90 \\
(12.02)\end{array}$ & - \\
\hline $\begin{array}{l}{\left[\mathrm{Fe}\left(\mathrm{C}_{11} \mathrm{H}_{10} \mathrm{~N}_{4} \mathrm{OS}\right)_{2} \mathrm{Cl}_{2}\right] \mathrm{Cl}} \\
\text { (Red) }\end{array}$ & 654 & $\begin{array}{c}8.45 \\
(8.53)\end{array}$ & $\begin{array}{c}42.5 \\
(42.0)\end{array}$ & $\begin{array}{c}3.91 \\
(3.80)\end{array}$ & $\begin{array}{c}15.2 \\
(16.0)\end{array}$ & $\begin{array}{c}9.65 \\
(9.78)\end{array}$ & $\begin{array}{c}16.00 \\
(16.28)\end{array}$ \\
\hline $\begin{array}{l}{\left[\mathrm{Hg}\left(\mathrm{C}_{11} \mathrm{H}_{10} \mathrm{~N}_{4} \mathrm{OS}\right)_{2} \mathrm{Cl}_{2}\right]} \\
\text { (Yellow) }\end{array}$ & 764 & $\begin{array}{l}25.03 \\
(25.0)\end{array}$ & $\begin{array}{c}33.04 \\
(32.90)\end{array}$ & $\begin{array}{c}3.30 \\
(3.00)\end{array}$ & $\begin{array}{c}13.9 \\
(14.0)\end{array}$ & $\begin{array}{c}8.2 \\
(8.0)\end{array}$ & $\begin{array}{l}9.00 \\
(8.80)\end{array}$ \\
\hline $\begin{array}{l}{\left[\mathrm{Sn}\left(\mathrm{C}_{11} \mathrm{H}_{10} \mathrm{~N}_{4} \mathrm{OS}\right)_{2} \mathrm{Cl}_{2}\right] \cdot 2 \mathrm{H}_{2} \mathrm{O}} \\
\text { (Light Yellow) }\end{array}$ & 717 & $\begin{array}{l}16.40 \\
(16.5)\end{array}$ & $\begin{array}{l}36.70 \\
(36.82)\end{array}$ & $\begin{array}{c}3.25 \\
(3.34)\end{array}$ & $\begin{array}{l}15.25 \\
(15.62)\end{array}$ & $\begin{array}{c}8.70 \\
(8.92)\end{array}$ & $\begin{array}{c}9.80 \\
(9.90)\end{array}$ \\
\hline $\begin{array}{l}{\left[\mathrm{Zn}\left(\mathrm{C}_{11} \mathrm{H}_{10} \mathrm{~N}_{4} \mathrm{OS}\right)_{2}(\mathrm{OAc})_{2}\right]} \\
3 \mathrm{H}_{2} \mathrm{O} \text { (Yellow) }\end{array}$ & 730 & $\begin{array}{c}8.45 \\
(8.90) \\
\end{array}$ & $\begin{array}{c}36.00 \\
(36.16) \\
\end{array}$ & $\begin{array}{c}4.08 \\
(4.38) \\
\end{array}$ & $\begin{array}{c}16.6 \\
(15.9)\end{array}$ & $\begin{array}{c}8.5 \\
(8.76)\end{array}$ & - \\
\hline
\end{tabular}


The molar conductivity data obtained in DMSO suggest that the complex $\left[\mathrm{Fe}\left(\mathrm{C}_{11} \mathrm{H}_{10} \mathrm{~N}_{4} \mathrm{OS}\right)_{2} \mathrm{Cl}_{2}\right] \mathrm{Cl}$ is 1:1 electrolyte and other three complexes are non-electrolytes in nature. The magnetic susceptibility properties of the complexes shows that the complex $\left[\mathrm{Fe}\left(\mathrm{C}_{11} \mathrm{H}_{10} \mathrm{~N}_{4} \mathrm{OS}\right)_{2} \mathrm{Cl}_{2}\right] \mathrm{Cl}$ is paramagnetic and three complexes are diamagnetic. The molar conductance values and magnetic susceptibility data are included in Table 2

Table 2. Melting point, Molar conductance and magnetic properties of metal complexes

\begin{tabular}{|c|c|c|c|}
\hline Compounds (color) & $\mathrm{mp} \quad{ }^{0} \mathrm{C}$ & \multirow[b]{2}{*}{$\begin{array}{l}\text { Molar Cond. } \\
\mathrm{Scm}^{2} \mathrm{~mol}^{-1}\end{array}$} & \multirow{2}{*}{$\begin{array}{c}\text { Magnetic } \\
\text { moment. } \\
\mu_{\text {eff }} \mu_{\mathrm{B}}\end{array}$} \\
\hline $\begin{array}{l}\mathrm{C}_{11} \mathrm{H}_{10} \mathrm{~N}_{4} \mathrm{OS} \text { Ligand } \\
\text { (Light Yellow) }\end{array}$ & $275-280{ }^{\circ} \mathrm{C}$ & & \\
\hline$\left[\mathrm{Fe}\left(\mathrm{C}_{11} \mathrm{H}_{10} \mathrm{~N}_{4} \mathrm{OS}\right)_{2} \mathrm{Cl}_{2}\right] \mathrm{Cl}$ (Red) & $260-265{ }^{0} \mathrm{C}$ & 45.5 & 4.75 \\
\hline$\left[\begin{array}{llll}\mathrm{Hg}\left(\mathrm{C}_{11}\right. & \mathrm{H}_{10} & \left.\mathrm{~N}_{4} \mathrm{OS}\right)_{2} & \mathrm{Cl}_{2}\end{array}\right]$ & $275-280{ }^{\circ} \mathrm{C}$ & 20.6 & Diamagnetic \\
\hline$\left[\mathrm{Sn}\left(\mathrm{C}_{11} \mathrm{H}_{10} \mathrm{~N}_{4} \mathrm{OS}\right)_{2} \mathrm{Cl}_{2}\right] \cdot 2 \mathrm{H}_{2} \mathrm{O}$ & $>300{ }^{0} \mathrm{C}$ & 25.6 & Diamagnetic \\
\hline$\left[\mathrm{Zn}\left(\mathrm{C}_{11} \mathrm{H}_{10} \mathrm{~N}_{4} \mathrm{OS}\right)_{2}(\mathrm{OAc})_{2}\right] 3 \mathrm{H}_{2} \mathrm{O}$ & $295-300^{0} \mathrm{C}$ & 18.5 & Diamagnetic \\
\hline
\end{tabular}

IR spectra

The IR spectra of ligand and complexes have been recorded and the probable assignments are given in the Table 3. The IR spectra of the complexes indicate that the ligand behaves as a bidentate and co-ordinate to the metal via $\mathrm{N}-3(\mathrm{C}-\mathrm{NH})$ and thiocarbonyl group $(\mathrm{C}=\mathrm{S})$ of ox diazole moiety. In the ligand, band appearing at $3456 \mathrm{~cm}^{-1}$ due to $\mathrm{NH}$ stretching is shifted to lower wave number at $3456 \mathrm{~cm}-3392 \mathrm{~cm}^{-1}$ in the complexes there by confirming the coordination through the nitrogen atom at position 3 of ox diazole ring. The band due to $v$ $\mathrm{C}=\mathrm{S}$ in the ligand at $1198 \mathrm{~cm}^{-1}$ is shifted to lower wave number at $1198-1128 \mathrm{~cm}^{-1}$ in the complexes. The shifting of $\mathrm{C}=\mathrm{S}$ stretching vibration to the lower wave number side as compared to the free ligand is indicative of participation of exocyclic S-atom at C-2 of ox diazole ring in coordination. New bands in the complexes in the region $595-560 \mathrm{~cm}^{-1}$ compared with IR spectra of free ligand have tentatively been assigned to M-N frequency ${ }^{11}$.

Table 3. Major IR bands of ligand(MBIMOT) and its metal complexes.

\begin{tabular}{ccccccccccccc}
\hline Compound & $\mathrm{N}-\mathrm{H}$ & $\mathrm{C}-\mathrm{H}^{1}$ & $\mathrm{C}-\mathrm{H}^{2}$ & $\mathrm{C}=\mathrm{N}$ & $\mathrm{C}-\mathrm{O}-\mathrm{C}$ & $\mathrm{C}=\mathrm{S}$ & $\mathrm{N}-\mathrm{N}$ & $\mathrm{M}-\mathrm{N}$ M-O M-Cl M-S \\
\hline MBIMOT $(\mathrm{L})$ & 3456 & 3107 & 2926 & 1516 & 1464 & 1198 & 926 & - & - & - & - \\
{$\left[\mathrm{Fe}(\mathrm{III}) \mathrm{L}_{2} \mathrm{Cl}_{2}\right] . \mathrm{Cl}$} & 3418 & 3057 & 2925 & 1538 & 1464 & 1128 & 938 & 573 & 420 & 361 & 344 \\
{$\left[\mathrm{Hg}(\mathrm{II}) \mathrm{L}_{2} \mathrm{Cl}_{2}\right]$} & 3443 & 3056 & 2924 & 1585 & 1451 & 1138 & 944 & 595 & 420 & 360 & 345 \\
{$\left[\mathrm{Sn}(\mathrm{II}) \mathrm{L}_{2} \mathrm{Cl}_{2}\right] .2 \mathrm{H}_{2} \mathrm{O}$} & 3392 & 3053 & 2926 & 1525 & 1465 & 1128 & 926 & 560 & 420 & 355 & 350 \\
{$\left[\mathrm{Zn}(\mathrm{II}) \mathrm{L}_{2}(\mathrm{OAc})_{2}\right] .3 \mathrm{H}_{2} \mathrm{O}$} & 3429 & 3056 & 2924 & 1585 & 1451 & 1138 & 976 & 595 & 420 & 360 & 345 \\
\hline
\end{tabular}

\section{${ }^{1}$ H NMR spectra}

$1=$ Aromatic, $2=$ Alkyl

The ${ }^{1} \mathrm{H}$ NMR spectra were recorded and probable assignments are tabulated in Table 4 . The ${ }^{1} \mathrm{H}$ NMR spectra of the ligand have the expected characteristic signals ${ }^{12-13}$. The $\mathrm{CH}_{3}$ proton shows singlet at $\delta 2.60$ and $\mathrm{N}-\mathrm{CH}_{2}$ proton at $\delta$ 5.68. In addition doublet peaks at $\delta 7.19$ and 7.50 may be due to aromatic protons of benzimidazole moiety and a peak at $\delta 10.62$ may be due to NH proton of ox diazole ring. This confirms the existence of ligand in thione form in liquid state. Signals observed in the complexes at region of $\delta 10.59-10.50^{13}$ due to the NH proton are either remained unaffected or shifted slightly downfield with reference to those of the parent ligand and the signal due to $\mathrm{CH}_{3}$ proton have shown downfield shift in the complexes $^{14}$. The $\mathrm{N}-\mathrm{CH}_{2}$ protons and aromatic protons have shown up field shifts in the complexes. In the complex $\left[\mathrm{Zn}(\mathrm{II}) \mathrm{L}_{2}(\mathrm{OAc})_{2}\right] \cdot 3 \mathrm{H}_{2} \mathrm{O}$ an additional peak at $\delta 1.93$ can be assigned for coordinated acetate(- $\left.\mathrm{OOCH}_{3}\right)$ group protons. These observations support the assigned structure to the complexes (Figure 2). 
Table 4. ${ }^{1} \mathrm{H}$ NMR spectra of ligand (MBIMOT) and its metal complexes ${ }^{13-14}$

\begin{tabular}{ccccccc}
\hline Compound & $\left(3 \mathrm{H},-\mathrm{CH}_{3}\right)$ & $\left(2 \mathrm{H}, \mathrm{N}_{-} \mathrm{CH}_{2}\right)$ & $(2 \mathrm{H}, \mathrm{Ar})$ & $(2 \mathrm{H}, \mathrm{Ar})$ & $(1 \mathrm{H}, \mathrm{NH})$ & $(6 \mathrm{H}, \mathrm{OAc})$ \\
\hline MBIMOT $(\mathrm{L})$ & 2.60 & 5.68 & 7.19 & 7.50 & 10.62 & - \\
{$\left[\mathrm{Fe}(\mathrm{III}) \mathrm{L}_{2} \mathrm{Cl}_{2}\right] . \mathrm{Cl}$} & 2.58 & 5.68 & 7.23 & 7.58 & 10.50 & - \\
{$\left[\mathrm{Hg}\left(\mathrm{III}_{2} \mathrm{~L}_{2} \mathrm{Cl}_{2}\right]\right.$} & 2.50 & 6.01 & 7.58 & 7.95 & 10.58 & - \\
{$\left[\mathrm{Sn}(\mathrm{III}) \mathrm{L}_{2} \mathrm{Cl}_{2}\right] .2 \mathrm{H}_{2} \mathrm{O}$} & 2.55 & 5.66 & 7.17 & 7.52 & 10.56 & - \\
{$\left[\mathrm{Zn}(\mathrm{II}) \mathrm{L}_{2}(\mathrm{OAc})_{2}\right] .3 \mathrm{H}_{2} \mathrm{O}$} & 2.50 & 6.01 & 7.58 & 7.95 & 10.59 & 1.93 \\
\hline
\end{tabular}

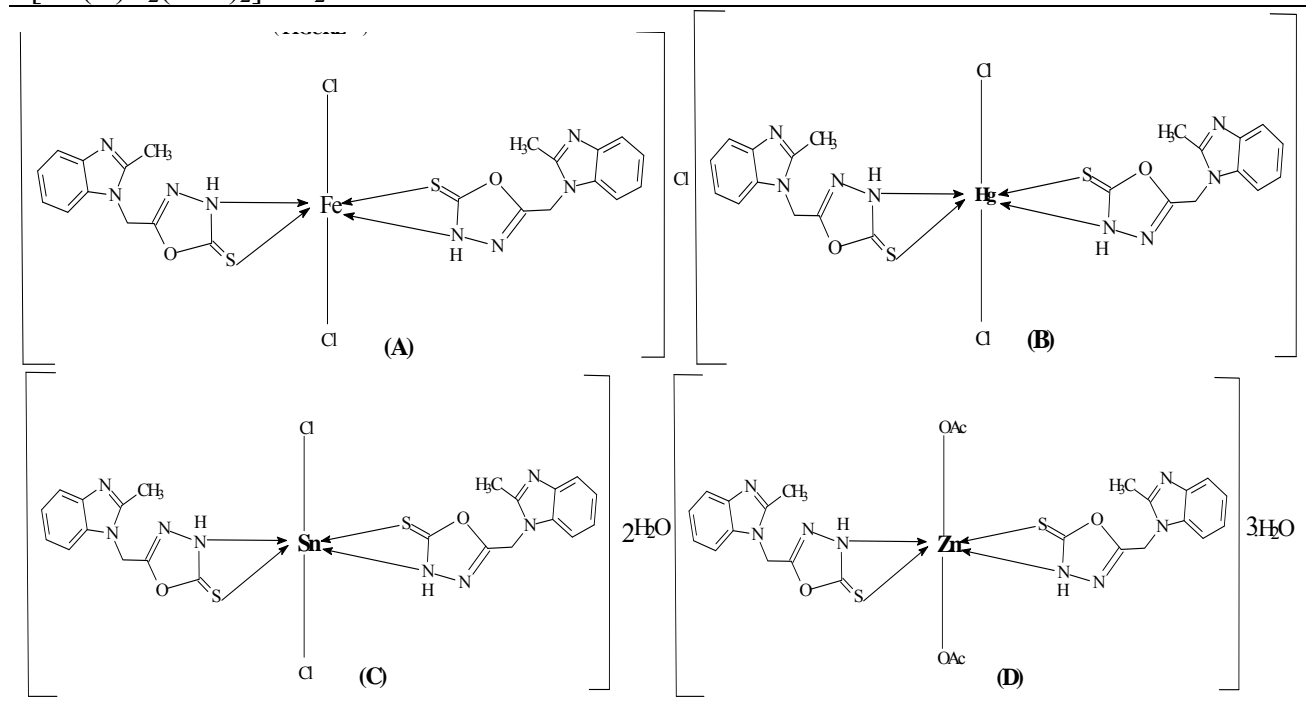

$\overline{\mathrm{OA}} \mathrm{c}=\mathrm{CH}_{3} \mathrm{COO}^{-}$

Figure 2. Assigned structure to the complexes

\section{EI-mass spectral studies}

The EI-Mass spectrum of the ligand(MBIMOT) showed a molecular ion peak at $\mathrm{m} / \mathrm{z} 246$ which is equivalent to its molecular weight. The base peak at $m / z 203$ is due to the fragment $\mathrm{C}_{10} \mathrm{H}_{10} \mathrm{~N}_{4} \mathrm{O}$. The fragmentation peaks at $\mathrm{m} / z 131$ and 73 are ascribed due to the cleavage of $\mathrm{C}_{8} \mathrm{H}_{7} \mathrm{~N}_{2}$ and $\mathrm{C}_{2} \mathrm{H}_{3} \mathrm{~N}_{2} \mathrm{O}$ respectively.

The EI-Mass spectrum of the complexes $\left[\mathrm{Fe}\left(\mathrm{C}_{11} \mathrm{H}_{10} \mathrm{~N}_{4} \mathrm{OS}\right)_{2} \mathrm{Cl}_{2}\right] \mathrm{Cl},\left[\mathrm{Hg}\left(\mathrm{C}_{11} \mathrm{H}_{10} \mathrm{~N}_{4} \mathrm{OS}\right)_{2}\right.$ $\left.\mathrm{Cl}_{2}\right]$., $\left[\mathrm{Sn}\left(\mathrm{C}_{11} \mathrm{H}_{10} \mathrm{~N}_{4} \mathrm{OS}\right)_{2} \mathrm{Cl}_{2}\right] .2 \mathrm{H}_{2} \mathrm{O}$ and $\left[\mathrm{Zn}\left(\mathrm{C}_{11} \mathrm{H}_{10} \mathrm{~N}_{4} \mathrm{O}\right)_{2}(\mathrm{OAc})_{2}\right] \cdot 3 \mathrm{H}_{2} \mathrm{O}$ showed a molecular ion peak $\mathrm{M}^{+}$at $\mathrm{m} / \mathrm{z} 654,764,717$ and 730 respectively which is equivalent to molecular weight of the complexes. The complex of Fe(III) has base peak at $m / z 246$ which is due to the loss of a molecule of ligand. The complexes of $\mathrm{Hg}(\mathrm{II}), \mathrm{Sn}(\mathrm{II})$ and $\mathrm{Zn}(\mathrm{II})$ have shown the base at $m / z 203$ which is due the fragmentation of ligand molecule into $\mathrm{C}_{10} \mathrm{H}_{10} \mathrm{~N}_{4} \mathrm{O}$ in these complexes.

\section{ESR spectra}

The ESR spectrum of $\mathrm{Fe}(\mathrm{III})$ complex $\left[\mathrm{Fe}(\mathrm{III}) \mathrm{L}_{2} \mathrm{Cl}_{2}\right]$.Cl. At RT exhibits three different $g$-values indicating magnetic anisotropy in the complex. The distorted structure of the complex is supported by its ESR spectrum recorded in solid state both RT and LNT, which shows anisotropic effects with g-tensor as g1, g2 and g3 respectively at 2.2222, 2.1345and 2.0341 in consistent with earlier report ${ }^{14}$. The trend $\mathrm{g} 1(2.30)>\mathrm{g} 2(2.27)>\mathrm{g} 3(2.05)$, for the complex suggest a rhombic octahedral geometry for the complex. 


\section{Thermogravimetric analysis}

The heating rates were suitably controlled at $10{ }^{\circ} \mathrm{C} \mathrm{min}^{-1}$ under nitrogen atmosphere and the weight loss was measured from the ambient temperature up to $1400{ }^{0} \mathrm{C}$. The thermo gravimetric studies reveal that no water molecules associated with the ligand. The decomposition of organic matter starts around $220{ }^{\circ} \mathrm{C}$. The thermogram of ligand showed first mass loss of $14 \%$ (cal. $13.6 \%$ ) at $219.3{ }^{\circ} \mathrm{C}$ which is due to loss $S$-atom of ligand molecule. After this TGA curve of ligand molecule showed maximum mass loss of $60 \%$ and is almost removed as a volatile components at about $750{ }^{\circ} \mathrm{C}$. The TGA curves of the complexes showed that the initial mass loss occurring within $100-120{ }^{\circ} \mathrm{C}$ range is interpreted as loss of moisture and hydrated water molecules during the chelate drying process and the second weight loss at around $200{ }^{\circ} \mathrm{C}$ range is due to loss of coordinated water molecules.

TGA curves of $\left[\mathrm{Zn}(\mathrm{II}) \mathrm{L}_{2}\left(\mathrm{CH}_{3} \mathrm{COO}\right)_{2}\right] .3 \mathrm{H}_{2} \mathrm{O}$ complex showed first mass loss of $7.9 \%$ (cal $=7.5 \%$ ) at $89.9{ }^{\circ} \mathrm{C}$ due to the loss of three hydrated water molecules. The second massloss of $36 \%$ occurring at $315{ }^{\circ} \mathrm{C}$ is due to the decomposition of two (2-methyl-benzimidazole) moieties. The third mass loss of $8.8 \%$ is due to the loss of one coordinated acetate ion. The final mass loss of $13 \%$ at $798{ }^{\circ} \mathrm{C}$ is due to the conversion $\mathrm{Zn}$ metal ion into $\mathrm{ZnO}$.

The $\left[\mathrm{SnL}_{2} \mathrm{Cl}_{2}\right] .2 \mathrm{H}_{2} \mathrm{O}$ complex shows a first weight loss of $4.00 \%$ (calcd.4.21\%) at 150 $220{ }^{\circ} \mathrm{C}$, indicating the loss of two hydrated water molecules. The second weight loss of $81.90 \%(81.98 \%)$ between $220-500{ }^{\circ} \mathrm{C}$ corresponds to the loss of a ligand and two chloride ions. When heated above $500{ }^{\circ} \mathrm{C}$, a plateau is obtained due to the formation of stable $\mathrm{SnO}$. The residue $16.40 \%$ (calcd. $16.50 \%$ ) agrees with the analytical result for the metal content.

\section{Electronic spectra and magnetic properties}

The Electronic spectra of the ligand and complexes was recorded in $10^{-5} \mathrm{M}$ solution in DMSO. The probable assignments are included in Table 5. The Electronic spectra of Fe(III) complex display two prominent bands ${ }^{10}$. A low intensity broad band around $12987 \mathrm{~cm}^{-1}$ and $16393 \mathrm{~cm}^{-1}$ is assignable to ${ }^{2} \mathrm{~T} 2 \mathrm{~g} \rightarrow{ }^{2} \mathrm{Eg}$ transition ${ }^{10,15}$. Another high intensity band at $25562 \mathrm{~cm}^{-1}$ is due to ligand - metal charge transfer. On the basis of electronic spectra distorted octahedral geometry around Fe(III) ion is suggested. The F(III) complex showed magnetic moment $4.75 \mathrm{BM}$, is slightly higher than the spin-only value $4.75 \mathrm{BM}$ expected for one unpaired electron, which offers possibility of an octahedral geometry ${ }^{15}$.

Table 5. UV-Vis spectra of free ligand and its metal complexes in $10^{-5} \mathrm{M}$ solution in DMSO solvent

\begin{tabular}{|c|c|c|c|c|c|}
\hline Compounds & $\begin{array}{c}\lambda_{\max } \\
\mathrm{nm}\end{array}$ & ABS & $\begin{array}{l}\text { Wave number } \\
\mathrm{cm}^{-1}\end{array}$ & $\begin{array}{c}\varepsilon \\
\text { L.mol }^{1} . \mathrm{cm}^{1}\end{array}$ & Transitions \\
\hline \multirow{4}{*}{ MBIMOT(L) } & 274 & 0.663 & 36496 & 15809 & $\mathrm{n}-->\pi^{*}$ \\
\hline & 320 & 0.435 & 31250 & 10372 & $\mathrm{n}-->\pi^{*}$ \\
\hline & 262 & 0.350 & 38167 & 22820 & (L-M,C.T) \\
\hline & 308 & 0.288 & 32467 & 18777 & (L-M,C.T) \\
\hline \multirow{5}{*}{ Fe(III)-MBIMOT } & 390 & 0.035 & 25641 & 2282 & $2 \mathrm{~T} 2_{(\mathrm{D})} \rightarrow^{2} \mathrm{E}_{(\mathrm{D})}$ \\
\hline & 460 & 0.025 & 21739 & 1630 & ${ }^{5} \mathrm{E}_{(\mathrm{D})} \rightarrow{ }^{5} \mathrm{~T}_{2(\mathrm{D})}$ \\
\hline & 610 & 0.026 & 16393 & 1695 & $\mathrm{~d}-\mathrm{d}$ \\
\hline & 770 & 0.026 & 12987 & 1695 & d-d \\
\hline & 276 & 0.556 & 36231 & 39865 & (L-M,C.T) \\
\hline \multirow[t]{2}{*}{ Hg(II)-MBIMOT } & 315 & 0.410 & 31746 & 29397 & (L-M,C.T) \\
\hline & 390 & 0.031 & 25641 & 2222 & (L-M,C.T) \\
\hline
\end{tabular}




\begin{tabular}{lccccc}
\hline & 253 & 0.327 & 39692 & 13450 & (L-M,C.T) \\
Sn(II)-MBIMOT & 275 & 0.335 & 36774 & 13650 & (L-M,C.T) \\
& 325 & 0.275 & 31255 & 11075 & (L-M,C.T) \\
& 395 & 0.038 & 25645 & 1438 & (L-M,C.T) \\
& 252 & 0.328 & 39682 & 13448 & (L-M,C.T) \\
Zn(II)-MBIMOT & 272 & 0.333 & 36764 & 13653 & (L-M,C.T) \\
& 320 & 0.270 & 31250 & 11070 & (L-M,C.T) \\
& 390 & 0.035 & 25641 & 1435 & (L-M,C.T) \\
\hline
\end{tabular}

\section{Biological activities}

The antimicrobial activity of the ligand and the complexes were determined by the disc diffusion technique ${ }^{16-18}$. The compounds were screened in vitro against. Escherichia coli and Salmonella paratyphi A. A $1 \mathrm{mg} / \mathrm{mL}$ solution in DMSO was used. The standard used was gentamycin sulphate. Media Used: Peptone-10 g, NaCl-10 g and Yeast extract 5 g, Agar $20 \mathrm{~g}$ in $1000 \mathrm{~mL}$ of distilled water.

Initially, the stock cultures of bacteria were revived by inoculating in broth media and grown at $37{ }^{\circ} \mathrm{C}$ for $18 \mathrm{~h}^{17-19}$. The agar plates of the above media were prepared and wells were made in the plate. Each plate was inoculated with $18 \mathrm{~h}$ old cultures $\left(100 \mu \mathrm{L}, 10^{-4} \mathrm{cfu}\right)$ and spread evenly on the plate. After $20 \mathrm{~min}$, the wells were filled with of compound at different concentrations. The control wells with Gentamycin were also prepared ${ }^{17-19}$. All the plates were incubated at $37{ }^{\circ} \mathrm{C}$ for $24 \mathrm{~h}$ and the diameter of inhibition zone were noted. The Table 6 contains diameter of inhibition zones (in $\mathrm{cm}$ ).

Table 6. Results of Antibacterial activities of ligand (MBIMOT) and its metal complexes Escherichia coli

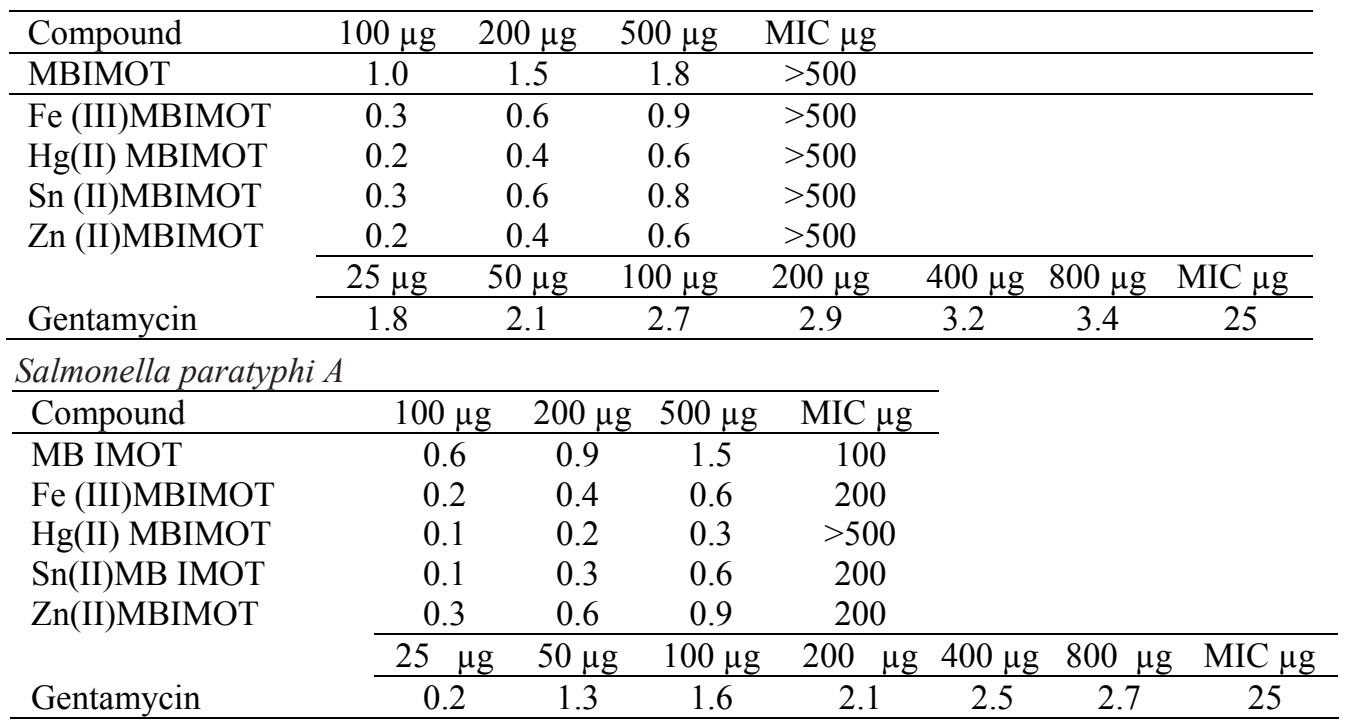

\section{Conclusion}

The ligand molecule acts as a bidentate ligand. The spectroscopic results show the involvement of $\mathrm{C}=\mathrm{N}($ at position 3 ) and $\mathrm{C}=\mathrm{S}$ (at position 2) groups in coordination to the central metal ion. On the basis of various techniques such as IR, ${ }^{1} \mathrm{H}$.NMR, Mass, ESR, UV-Vis 
Molar conductance and Thermal studies used for the characterization of metal-complexes a rhombic octahedral geometry for Fe(III) complex and octahedral geometry for $\mathrm{Hg}$ (II), $\mathrm{Sn}$ (II) and $\mathrm{Zn}(\mathrm{II})$ complex is proposed. In view of the foregoing discussions, the high melting points and insolubility in common organic solvents, we have assigned following probable structure of the complexes ${ }^{10}$ (Figure 2).

\section{Acknowledgement}

The author is indebted to Prof A M A Khader Research Supervisor at Department of Chemistry Mangalore University Mangalore for Supervising this research work. The author is thankful to SAIF IIT Chennai for providing the IR, ${ }^{1} \mathrm{H}$ NMR, Mass, UV-Vis spectra and TGA data. The author is also thankful to SAIF IIT Mumbai for providing the ESR spectral data. The thanks also are due to The Principal Anjuman Engineering College, Bhatkal for providing the Research facilities.

\section{References}

1. Ramanpreet Walia, Md Hedaitullah, Syeda Farha Naaz, Khalid Iqbal and HS. Lamba. IJRPC, 2011, 1(3), 565-574.

2. Mishra A K, Gautam V, Gupta A, Bansal R, Bansal P, Kumar S and Gupta V, $J$ Pharm Res., 2010, 3(2), 371-378.

3. Belkadi M and Othman A A, ARKIVOC, 2006, xi, 183-195.

4. Havaldar F H, and Patil A R, Asian J Chem., 2008, 20(1), 97-101.

5. Aydogan F, Turgut Z, Afiye S E and Ocal N, Turk J Chem., 2002, 26(2), 159-170.

6. Pandey O.P, Sengupta S K and Tripathy S C, Bull Chem Soc Jpn., 1985, 58, 2395-2398.

7. Singh M, Pandey A K, Butcher R J and Singh N K, Polyhedron, 2009, 28(3), 461466; DOI:10.1016/j.poly.2008.11.046

8. Mendham J, Denny R C, Barnes J D and Thomas M J K, Vogel's Text Book of Quantitative Analysis, 2000, ${ }^{\text {th }}$ Ed., 495-498.

9. Gudasi K, Patil M and Vadavi R, J Serb Chem Soc., 2007, 72, 357-366.

10. Shayma A S, Yang F and Abbas A S, Eur J Sci Res., 2009, 33(4), 702-709.

11. Kiranmai K, Prashanthi Y, Subhashini N J P and Shivaraj, J Chem Pharm Res., 2010, 2(1), 375-384

12. Kulkarni A D, Patil S A and Badami P S, Int J Electrochem Sci., 2009, 4, 717-729

13. Deshbandhu Joshi, ARPB, 2011, 1(1), 45-50.

14. Afaf H. E, Fahmy H H and Ali Abdelwahed S H, Molecules, 2000, 5, 1429-1438

15. Ahmed A. H. Al-Amiery, Yasmien K. Al-Majedy, Sallal A. Abdulhadi and Ali H. Sadoon African J Pure and Applied Chem., 2009, 3(11), 218-227.

16. Kazi S A A. J Chem., 2011, 8(S1), S127-S136; DOI:10.1155/2011/280682

17. Threfall E J, Fisherr I S T, Ward L, Tschape H and Gerner S P, Microb Drug Resist., 1999, 5, 195-199.

18. Walker R D, Antimicrobial Therapy in Veterinary Medicine, 2000, 12-26.

19. Collins C H and Lyne, Microbiological Methods, 1976, $4^{\text {th }}$ Ed., 235-240. 